\title{
GEOTOURISTIC POTENTIALITY OF HAMMAM FARAUN GEOTHERMAL AREA, SOUTH SINAI GOVERNORATE, EGYPT
}

\author{
Shawky, A. ${ }^{1}$, El-Anbaawy, M. I. ${ }^{1}$, Shallaly, N. A. ${ }^{1}$, Abdelhafiz, H. E. ${ }^{2}$ \\ ${ }^{1}$ Geology Department, Faculty of Science, Cairo University, Giza, Egypt. \\ ${ }^{2}$ National Research Institute of Astronomy and Geophysics (NRIAG), Helwan, Cairo, Egypt.
}

\begin{abstract}
Hammam Faraun area is considered as one of the main geothermal areas in Egypt, as such its geotouristic attractions are inventoried and assessed in the present study.

These attractions are represented essentially in Gebel Hammam Faraun, the coastal area facing it, thermal springs, karstic caves, travertine, and volcanic occurrences. Gebel Hammam Faraun represents an outstanding geomorphosite in West Sinai and together with the Gulf of Suez it forms an interesting mountainous-shore landscape. Thermal springs which represent the hottest ones in Egypt recognize this area and have important benefits in balneotherapy and are under investigation for the use in power production. Together with the thermal springs, the karstic caves that are used as natural saunas in the area represent the main geotouristic attractions. Travertine is an important yet not known geologic feature in Hammam Faraun area however, being found in small patches lowers its geotouristic potentiality. Diverse volcanic bodies in the form of sills, dykes and flows are remarkable features that add to the geotouristic potentiality of the study area. It is demonstrated that this area is remarkable for its diverse landscape, active geothermal phenomenon, and outstanding geological, and geomorphological features. Thus, the area has a geotouristic and geoheritage potentiality that can attract both geologists and public. The geotouristic potentiality of Hammam Faraun can be attributed to both scenic and educational values of its geologic features. Moreover, the study gives some recommendations for geotourism development at the area. Furthermore, a coupling between geothermal energy use and geotourism development in the area could support environmental conservation and sustainable development goals in Sinai Peninsula.
\end{abstract}

Keywords: Geotourism, geoheritage, Hammam Faraun, thermal springs, travertine, karstic caves, geothermal energy \& ecotourism, Gulf of Suez.

\section{INTRODUCTION}

Geoheritage is a new rapidly emerging discipline of geology that is interested in special and representative geosites which are geologic areas with significant (or may be exceptional) scientific, educational, cultural, or aesthetic values. This discipline has a broad area of interest including occurrences of minerals, rocks, fossils, soils, landforms and geological processes (e.g. ProGEO, 2011; GSA, 2012). Geosites offer good chances for better understanding the 'living Earth', its resources and hazards and are considered as windows into geologic past (Migoń and Pijet-Migoń, 2017).

Geotourism 'geological tourism' which is one of the main utilizations of geoheritage and can be defined as a kind of sustainable, natural area tourism that allow tourists and visitors to travel in a territory in order to enjoy and learn from earth heritage (e.g. Dowling and Newsome, 2006; Farsani et al., 2012). Geotourism is focused on geology and landscape. Thus, it adds to the ecotourism's biotic dimension (flora and fauna) by combining a third dimension of the abiotic environment (Newsome and Dowling, 2010).

Areas of volcanic and geothermal features are important geotouristic attractions. Some of these areas have been previously known as national parks and have been nominated to become geoparks (ErfurtCooper, 2010). Geoheritage and geotourism of geothermal areas including hot springs areas at several places worldwide drew the attention of many authors and has been focused in many research works recently (e.g. Erfurt-Cooper and Cooper, 2010). 
Egypt possesses a significant variety of geotouristic attractions from the scale of large landscapes to the scale of small rocks and fossils. Such attractions are of both scientific and scenic values. These include different igneous, metamorphic and sedimentary mountains, caves, hot springs, sand dunes and other aeolian features, and ancient mines, etc. Thus, geotourism was once considered as an Egyptian secret treasure (Whaley, 2006; Abdel Maksoud and Hussien, 2016). The research of Geotourism and geoheritage has increased progressively in the last decade. Fortunately, the Egyptian authorities' interest in such type of tourism is becoming more notable.

Geothermal manifestations in Egypt are inspected mainly in the form of natural hot or thermal springs. Hammam Faraun (Pharaoh's Bath) geothermal area is located in the west central part of Sinai Peninsula, on the eastern shore of the Gulf of Suez rift. It is about $250 \mathrm{~km}$ distant from Cairo (Fig. 1). It represents one of the main geothermal areas in Egypt visited by both geologists and public.

Hammam Faraun (HF) hot springs have been flowing for at least thousands of years and had already been known at the time of the pharaohs. Soldiers and miners of the pharaohs of the Third Dynasty took hot baths in these springs as early as a thousand years before Moses' time (e.g. LaMoreaux, 2001).

The area is an important part of the Suez rift with its significant geohistory. The present study aims to evaluate the geotouristic potentiality and demonstrate the geoheritage value of the geological attractions of HF geothermal area. The attractions include the Gebel HF-shore landscape, thermal springs, karstic caves, travertine, and volcanic bodies.

Fig. 1: Location map of the study area (HF). The background is a physical relief map of Egypt modified after Wikimedia Commons.

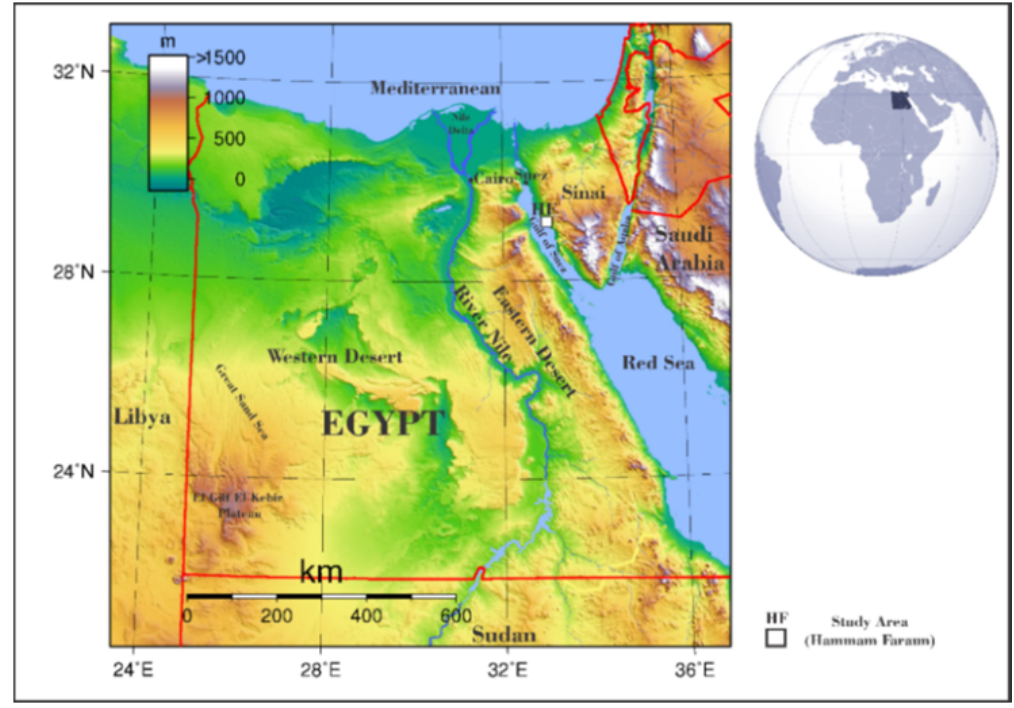

GEOLOGIC SETTING

The study area constitutes the north-western corner of the Hammam Faraun rift block (a crustal-scale half- graben) which is located within the central dip province of the Gulf of Suez rift (Fig. 2). The HF riftblock tilts gently $\left(10-20^{\circ}\right)$ towards the northeast. It is bounded by the NW- oriented extensional Hammam Faraun master fault (HFF) to the west, and the NW-striking Thal Fault to the east. The southern boundary of this rift block is marked by the prominent E-W trending Baba-Markha fault.

The Hammam Faraun Fault (HFF; Fig. 2) is more than $25 \mathrm{~km}$ long, dipping steeply to the southwest (60-80 and has displacements up to $5 \mathrm{~km}$. In the map view, the fault has a zigzag pattern with the dominant fault segments strike NW-SE, where the other segments are oriented N-S, NNE and WNW (e.g. Moustafa \& Abdeen 1992; Gawthorpe et al. 2003). The stratigraphy of HF rift block is differentiated into three sequences: pre-rift, syn-rift and post-rift (Fig. 3). The pre-rift (Pre- Miocene) sequence includes from base to top, a sandstone assemblage, a mixed facies assemblage, and a carbonate assemblage. The pre-rift sequence is followed by a syn-rift (Oligocene- Miocene) one that includes early rift volcanics in addition to clastics and evaporites. The two sequences are followed by a post-rift (Quaternary) sequence (e.g. Moustafa and Abdeen, 1992; Moustafa, 1996). 
Geotouristic potentiality of Hammam Faraun geothermal area

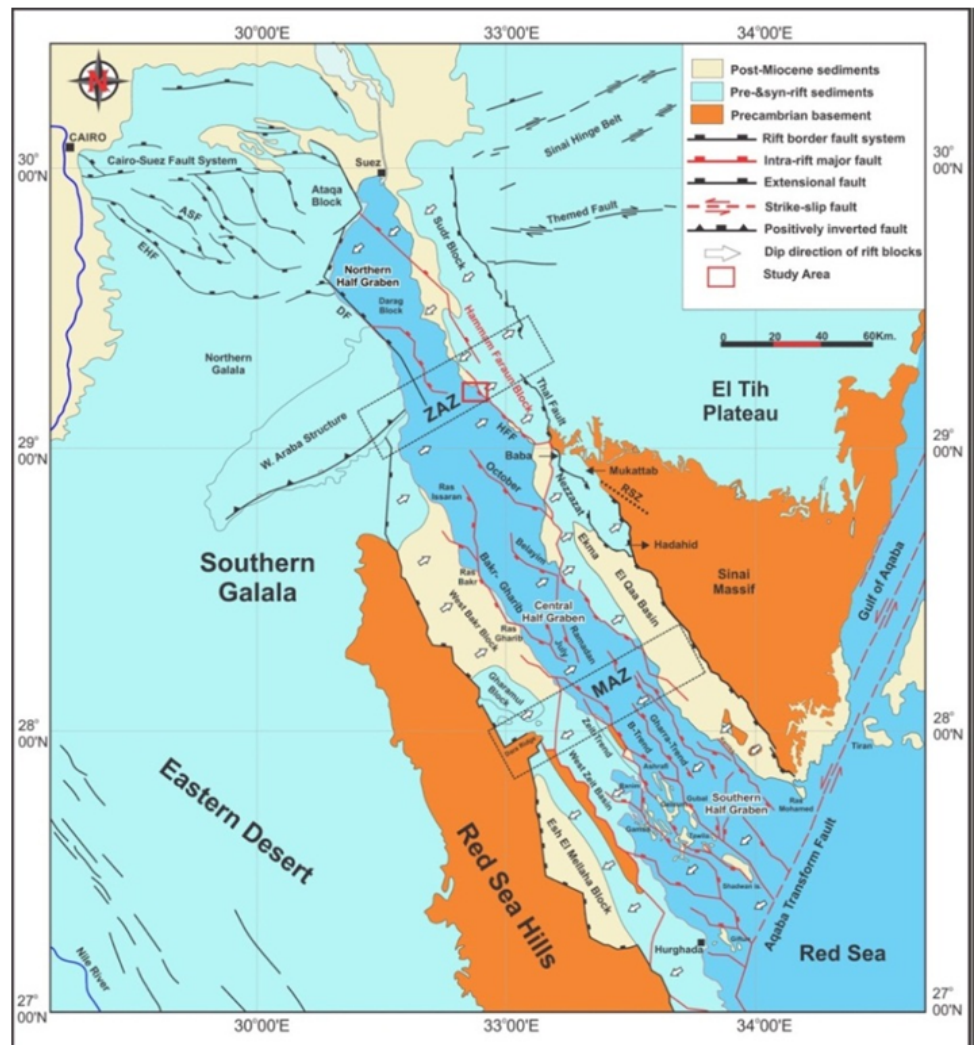

Fig. 2: The study area location on the regional geologic map of the Gulf of Suez rift and Sinai Peninsula (after Moustafa and Khalil, 2020).

Fig. 3: Stratigraphic column of HF rift block showing surface and subsurface rock units (after Moustafa, 1996).

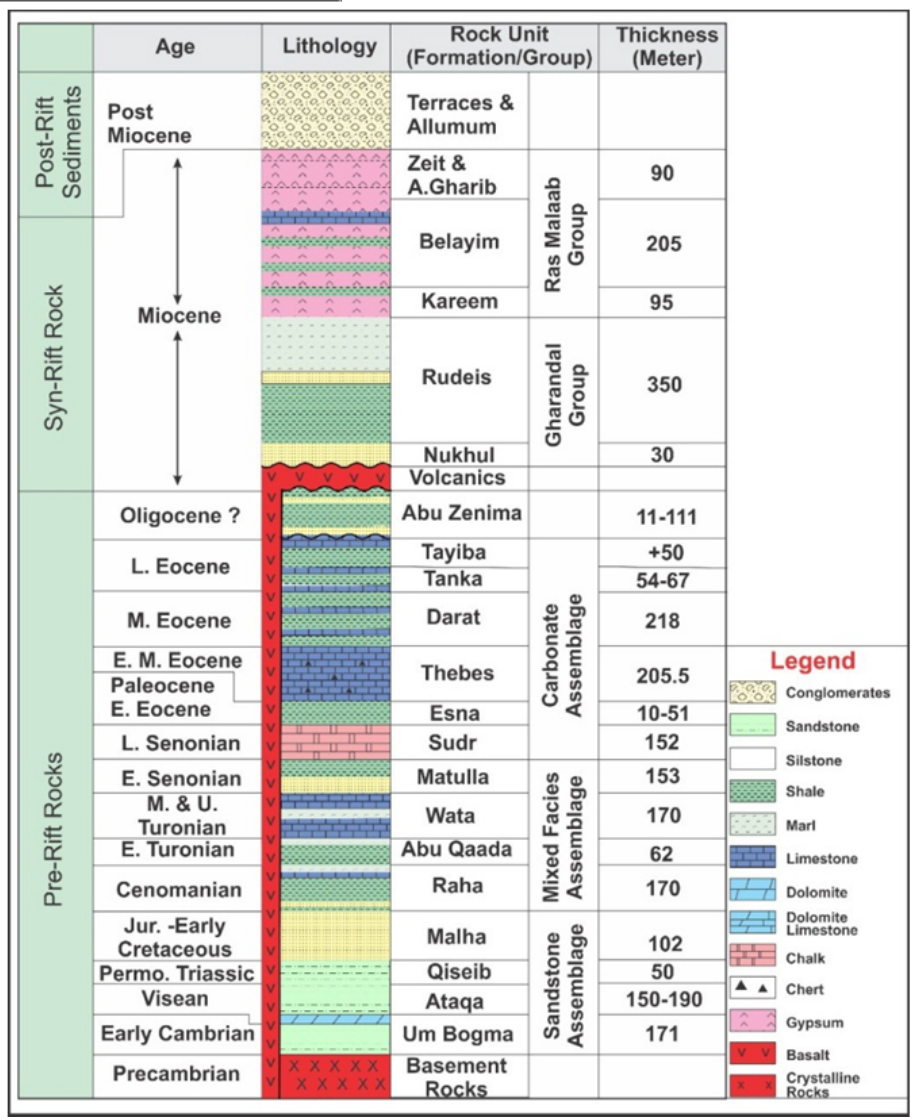

Geomorphologically, the area is one of the main hilly landmarks at the outwash plain west to the vast El Tih plateau occupying central Sinai (see Fig. 2). However, Gebel Hammam Faraun is one of the 
vigorous topographies in the Gulf of Suez coastal plain. It represents the most northern peak of three peaks forming the so called Hammam Faraun range (Moon and Sadek, 1923). This range comprises Gebel Hammam Faraun, Gebel Thal, and a southern unnamed peak of altitudes approaching 500 m (Fig. 4).

Hammam Faraun is characterized by a desert climate. It has mild winter and hot summer. The average temperature ranges between $17^{\circ}$ in January and $33^{\circ}$ in July. The average annual temperature is about $25^{\circ}$. The annual rainfall amounts to $15 \mathrm{~mm}$ and the maximum rainfall amounts to $26 \mathrm{~mm}$.

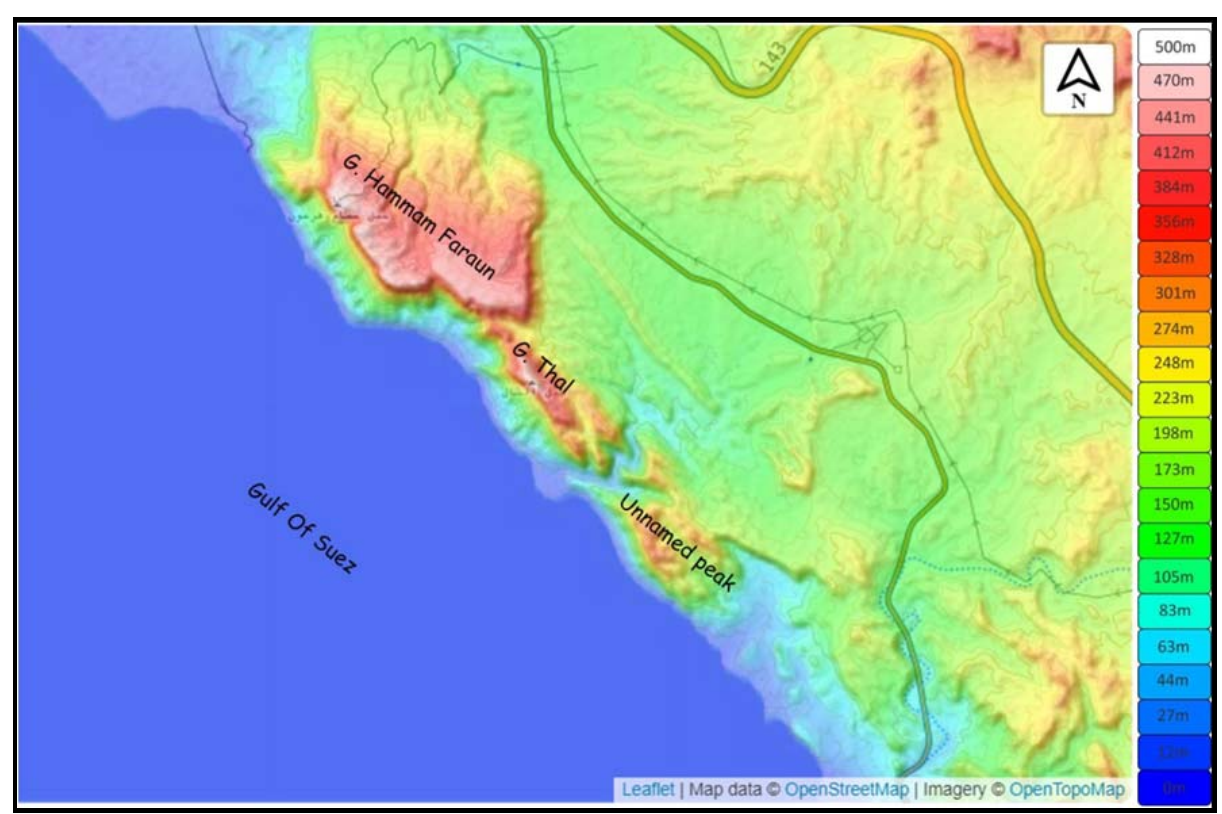

Fig. 4: A digital

elevation model (DEM) map for the so called Hammam Faraun range which includes Gebel Hammam Faraun of altitude $\sim 500 \mathrm{~m}$ (Source: Open Street maps and Open Topo maps).

\section{METHODOLOGY}

The study began with reviewing and evaluating the previous work including previous geologic and geomorphologic maps. This was followed by field investigation through a ten days field trip.

The field study involved lithologic description for the different rock units, detection and delineation of structural elements, and collection of rock samples for petrographical studies. In-situ measurements for the thermal water's physical properties and salinity in the field using a portable probe and collection of some water samples for further chemical analysis were conducted. Sampling took place in august 2020.

Thermal water samples were collected in high-density polythene bottles that are washed with $1 \mathrm{M}$ nitric acid and washed with the thermal springs water itself prior to collection. An important step was the detailed photographing of the different geologic elements of the area.

Thin sections for carbonate rocks, travertine and volcanic rocks were constructed and studied under polarizing microscope. Laboratory analysis for thermal waters included measurements of major ions and trace ions. Major anions and cations as well as trace elements were estimated using atomic absorption spectroscopy. These analyses were conducted at the water laboratory of the Soils and Water Use Department at the National Research Center of Egypt.

\section{RESULTS AND DISCUSSION}

The studied geological attractions of HF area are inventoried and discussed in this study in terms of geological description, field occurrence, geological significance and geotouristic potentiality. Table 1 lists the detailed coordinates of the locations of such attractions. A geotouristic map for these attractions is constructed (Fig. 5). Moreover, this map is supported by a collection of close-up views of these attractions from satellite imagery (Fig. 6).

Each of these attractions is discussed separately in the following sections: 
Geotouristic potentiality of Hammam Faraun geothermal area

Table 1: Locations of the geological attractions of Hammam Faraun area which are evaluated in this study and shown on the geotouristic map (Fig. 5).

\begin{tabular}{|l|l|l|}
\hline \multicolumn{1}{|c|}{ Attraction } & Longitude & Latitude \\
\hline 1- Gebel Hammam Faraun- Shorelandscape & $\begin{array}{l}\text { From } 29^{\circ} 04^{\prime} 54^{\prime \prime} \mathrm{N} \text { to } \\
29^{\circ} 12^{\prime} 54^{\prime \prime} \mathrm{N}\end{array}$ & $\begin{array}{l}\text { From } 32^{\circ} 56^{\prime} 42^{\prime \prime} \mathrm{E} \text { to } \\
32^{\circ} 58^{\prime} 30^{\prime \prime} \mathrm{E}\end{array}$ \\
\hline 2- Thermal Springs & $29^{\circ} 11^{\prime} 50.37^{\prime \prime} \mathrm{N}$ & $32^{\circ} 57^{\prime} 20.42^{\prime \prime} \mathrm{E}$ \\
\hline 3- Karstic Caves & $29^{\circ} 11^{\prime} 53.3^{\prime \prime} \mathrm{N}$ & $32^{\circ} 57^{\prime} 18.9^{\prime \prime} \mathrm{E}$ \\
\hline 4- Travertine & $29^{\circ} 11^{\prime} 36.4^{\prime \prime} \mathrm{N}$ & $32^{\circ} 57^{\prime} 29.2^{\prime \prime} \mathrm{E}$ \\
\hline 5- Volcanic bodies: & $29^{\circ} 12^{\prime} 39.08 " \mathrm{~N}$ & $32^{\circ} 57^{\prime} 5.65^{\prime \prime} \mathrm{E}$ \\
\hline - Flows & $29^{\circ} 11^{\prime} 08.0^{\prime \prime} \mathrm{N}$ & $32^{\circ} 57^{\prime} 52.1^{\prime \prime} \mathrm{E}$ \\
- Sill & $29^{\circ} 11^{\prime} 08.0^{\prime \prime} \mathrm{N}$ & $32^{\circ} 57^{\prime} 52.1^{\prime \prime} \mathrm{E}$ \\
\hline
\end{tabular}

Fig. 5: Geotouristic map of Hammam Faraun area showing the localities of the promising geological attractions discussed in the study (Source of the base map: Esri).

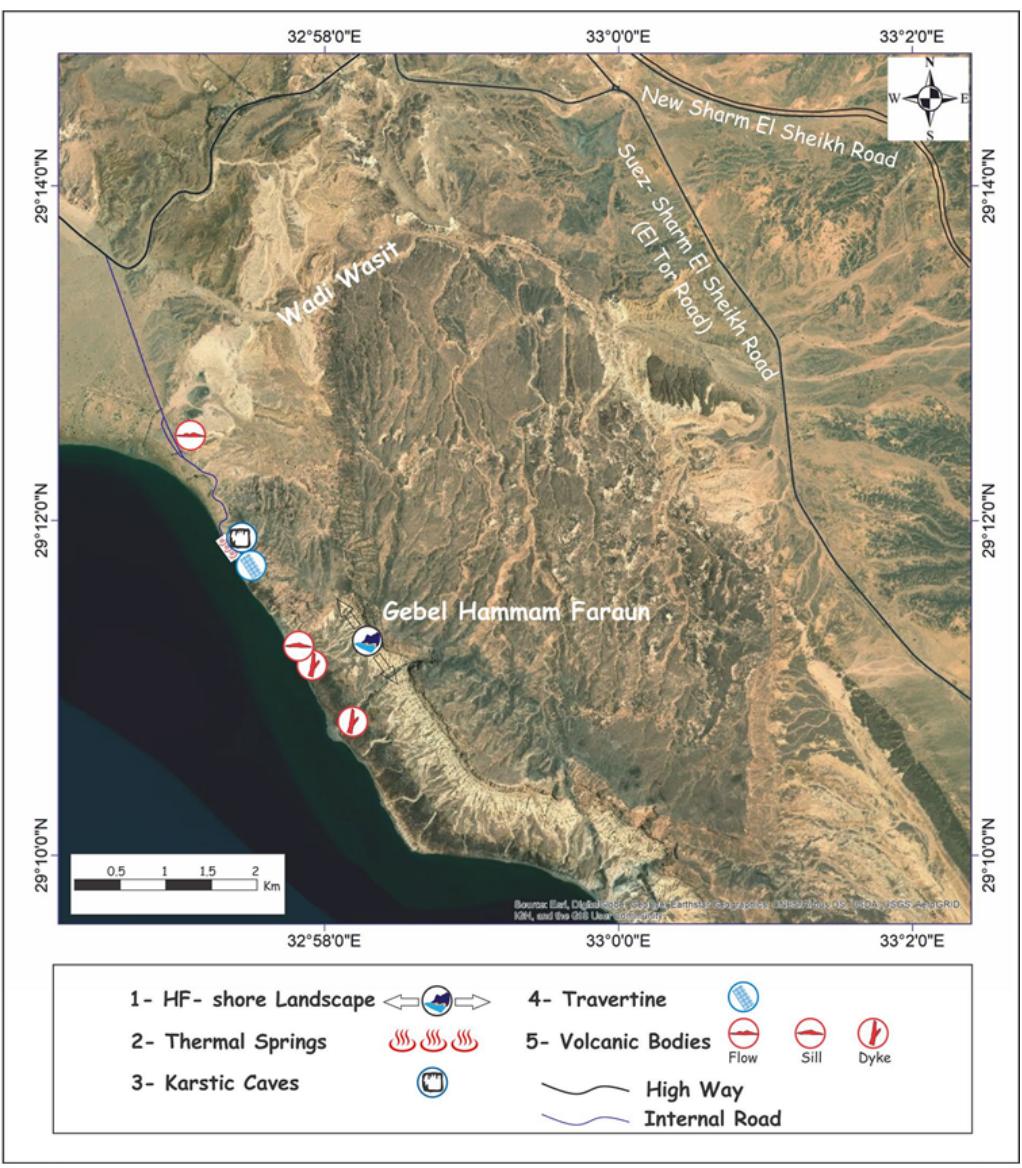

\section{Gebel HF- shore landscape}

The Gebel HF- shore landscape forms a conspicuous geomorphosite at the narrow coastal plain of the Gulf of Suez in west Sinai. This is attributed to its natural (geo) and historical heritage value offering it a relatively high geotouristic potentiality. Gebel Hammam Faraun is a $500 \mathrm{~m}$ high peak forming a prominent landmark for the travelers passing down the Gulf of Suez and Sinai Peninsula through El Tor high Road. As mentioned above it is the first peak that to come into view of the three peaks of HF range that also includes Gebel Thal and another third unnamed peak (see Fig. 3). This mountain itself is a part of the footwall of the coastal Hammam Faraun major fault (HFF) where the hanging wall is found in the subsurface in the Gulf of Suez. Thus, it forms a famous fault-line scarp (of the major HFF) in the eastern shore of the Gulf of Suez rift. A very narrow coast is formed in front of Gebel Hammam Faraun having the breadth of a path that visitors use. The scenery of the cliff together with the shore and thermal springs (discussed later) boasts and characterizes this important area in Sinai (Fig. 7). 


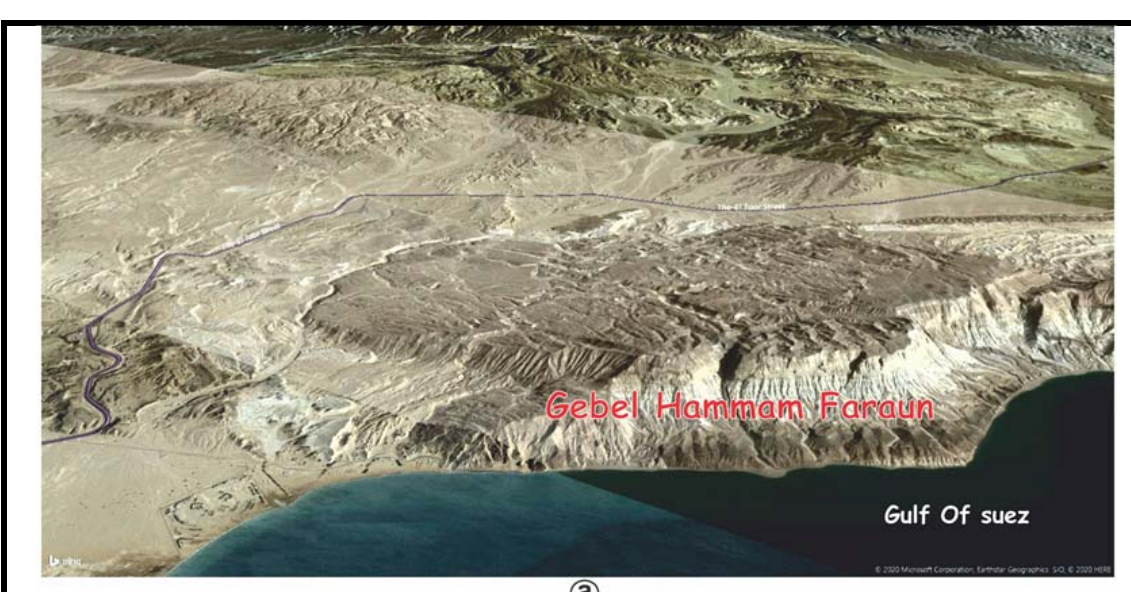

(a)

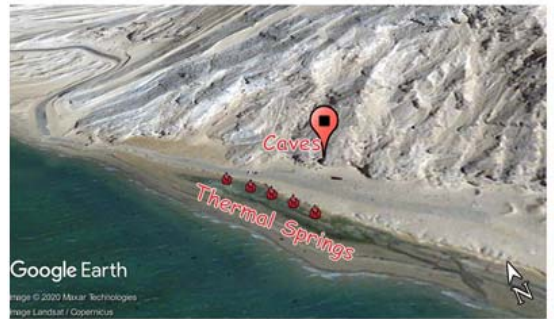

(b)

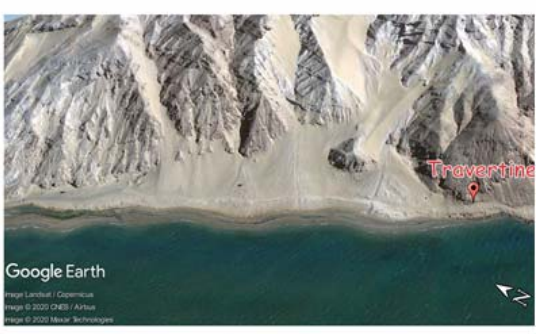

(C)

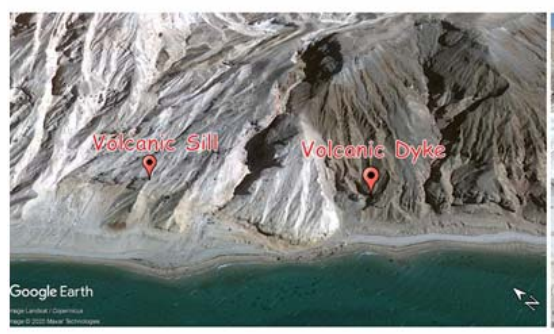

(d)

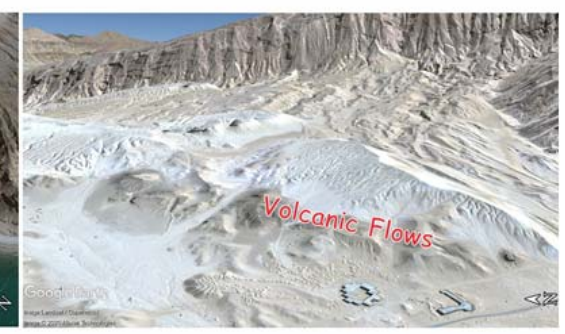

(e)
Fig. 6: Satellite images for Hammam Faraun geotouristic attractions a) The whole Gebel HF-shore landscape b) Thermal springs and caves c) Travertine d) Volcanic sill and dyke e) Volcanic flows (Source: Google Earth and Bing).

Gebel HF has a thickness of $500 \mathrm{~m}$ and as being a part of the large HF fault block, it encompasses a pre-rift mixed carbonate-clastic cretaceous assemblage. This is followed by Eocene carbonate assemblage that's overlain by early-rift and syn-rift clastics which are overlain by Miocene evaporites. The whole succession is covered by Quaternary deposits which are mainly wadi deposits .The following Formations are encountered at the surface (from bottom to top): Matulla, Sudr, Esna, Thebes, Darat, Tanka, Tayiba and Abu Zenima formations. The overlying Miocene strata are undifferentiated and covered by Quaternary deposits. A group of faults as well as folds are encountered in the study area. A $3 \mathrm{~d}$ geologic map of the study area displaying these geologic rock units and structures is shown in Fig. 8.

Gebel HF is predominantly formed of the partially dolomitized pre-rift Thebes Formation of Early Eocene age (Fig. 9a). Thebes formation includes three lithofacies; namely, matrix - supported bioclastic brecciated calc-rudite, skeletal grainstone-packstone and Foraminiferal wackestone-packstone facies which were interpreted by Hirani (2014) and others as debris flows, turbidites and slope deposits respectively. Dolomite bodies within the Thebes Formation (fig. 9b) occur in the form of massive and stratabound geometries (Hollis et al., 2017; Hirani et al., 2018a and b) (see the geologic map Fig. 8). Within these lithofacies the allochems are replaced by dolomite as well as some micritic matrix. Dolomite cement is also represented with some dedolomitized parts. Under petrographic microscope, fossiliferous (mainly foraminiferal) parts of the Thebes Formation show Nummulites, Operculina, planktonic Foraminifera and Echinoid fragments embedded in micrite matrix (fig. 9c). Moreover, dolomitized parts show obvious dolomite crystals (fig. 9d) where euhedral to subhedral dolomite crystals with or without zoning are commonly observed. 


\section{Geotouristic potentiality of Hammam Faraun geothermal area}

Fig. 7: Field photos for Gebel HFshore landscape a) Distant view taken from the internal road b) Close view; visitors who bath in the thermal springs area are obvious.
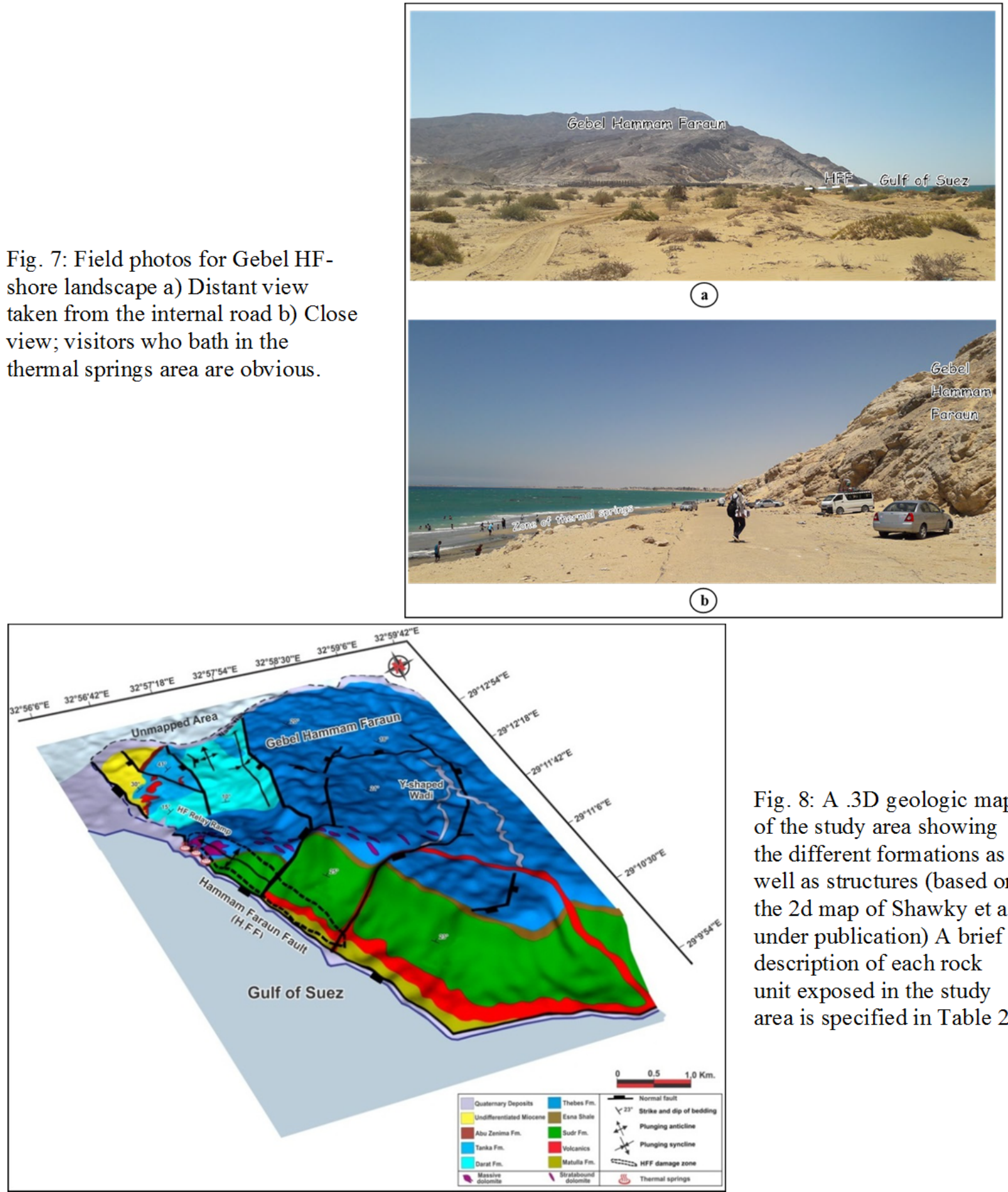

Fig. 8: A .3D geologic map of the study area showing the different formations as well as structures (based on the $2 \mathrm{~d}$ map of Shawky et al; under publication) A brief description of each rock unit exposed in the study area is specified in Table 2 .

\section{Thermal springs}

A strip of thermal springs exists in the area, emerging along the coastline at the shore cliff (fault scarp) of Gebel Hammam Faraun (Fig. 10a). The linear distribution of such springs indicates that they are structurally controlled by the Hammam Faraun Fault (Fig. 10b). They are issuing from the Eocene carbonates of the Thebes Formation. There are about 10 springs that are $3 \mathrm{~m}$ wide and have a depth of about 50 to $80 \mathrm{~cm}$. The water is bright blue in color. The water discharged from the springs, flow slowly forming microchannels (Fig. 10c) that pass into a shallow lake. The depth of water in this lake is not exceeding $1 \mathrm{~m}$. The bottoms and the margins of the lake are colonized with thermophiles and cause the water to be stained with striking colors of yellow, green, and black (Fig. 10d). 
Table 2: Lithological description of the surface rock units encountered in the study area from top to bottom.

\begin{tabular}{|l|l|}
\hline Formation (Age) & \multicolumn{1}{|c|}{ Lithology } \\
\hline 9. Friable deposits (Quaternary) & Wadi deposits and beach sands and gravels. \\
\hline $\begin{array}{l}\text { 8. Undifferentiated rock units } \\
\text { (Miocene) }\end{array}$ & $\begin{array}{l}\text { Intercalation of sandy shale to sandstone with minor carbonates and } \\
\text { topped by evaporite massive beds. }\end{array}$ \\
\hline $\begin{array}{l}\text { 7. Tayiba -Abu Zenima } \\
\text { (Oligocene- Early Miocene) }\end{array}$ & $\begin{array}{l}\text { Sandstone and siltstone beds topped by conglomerate beds and } \\
\text { limestone ledges. }\end{array}$ \\
\hline 6. Tanka (Middle-Late Eocene) & $\begin{array}{l}\text { Limestones, highly affected by faults and volcanic invasions along } \\
\text { the northern part of the area. }\end{array}$ \\
\hline 5. Darat (Middle Eocene) & Limestones exposed in the northwestern part of the area. \\
\hline 4. Thebes (Early Eocene) & $\begin{array}{l}\text { Fractured, partially dolomitized limestones. Chalky (upper part) and } \\
\text { cherty (lower part). }\end{array}$ \\
\hline 3. Esna (Paleocene) & $\begin{array}{l}\text { Shale with argillaceous limestone intercalations, exposed as thin bed } \\
\text { at the base the southern part of the Thebes Fm. exposure. }\end{array}$ \\
\hline 2. Sudr (Late Cretaceous) & $\begin{array}{l}\text { Chalky limestone, occasionally bituminous and phosphatic with thin } \\
\text { flint beds and volcanic sills. }\end{array}$ \\
\hline 1. Matulla (Middle Cretaceous) & Shale with thin limestone intercalations, intruded by volcanic bodies. \\
\hline
\end{tabular}

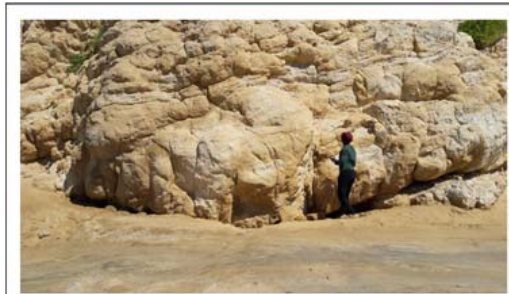

(a)

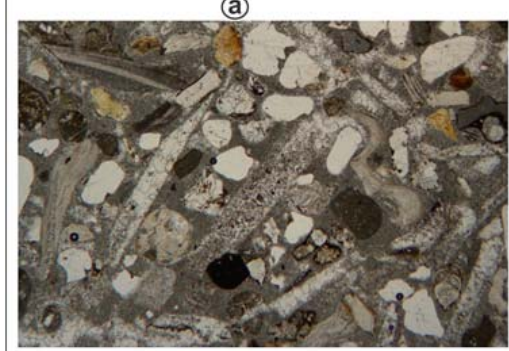

(C)

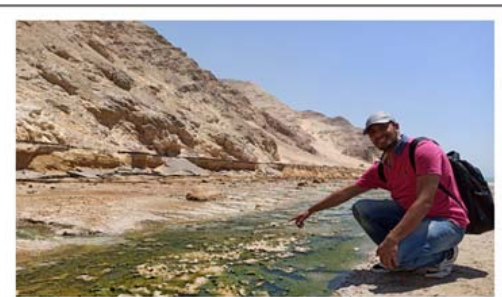

(b)

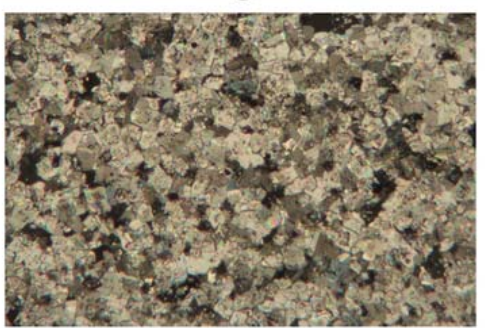

(d)

Fig. 9: Field photos for the Early Eocene Thebes Fm. exposed in hammam Faraun area. a) Undolomitized limestone part b) the dark colors indicate the dolomitized parts facing the area of the hot springs. c) Thin section showing the fossiliferous content of the same formation.

d) Euhedral to subhedral dolomite rhombs within the dolomitized parts.

Fig. 10: a) Hammam Faraun springs with obvious steam. b) Close up view of the springs showing their linear distribution. c) Microchannels formed from the flow of the water. d) The margin of lake is colonized with microbial accumulations and blackening of the beach sediments.

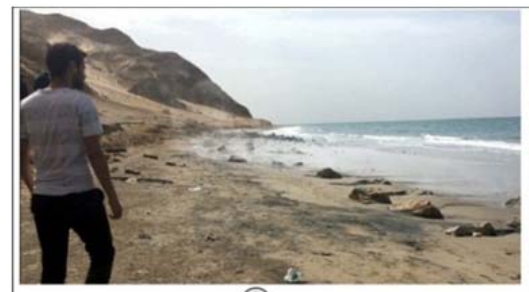

(a)

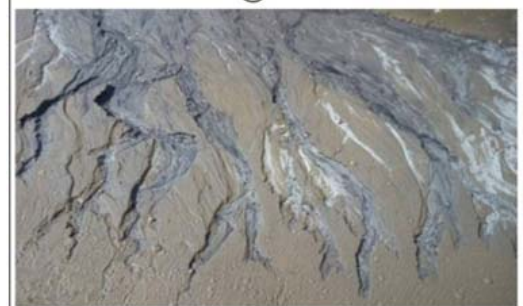

C)

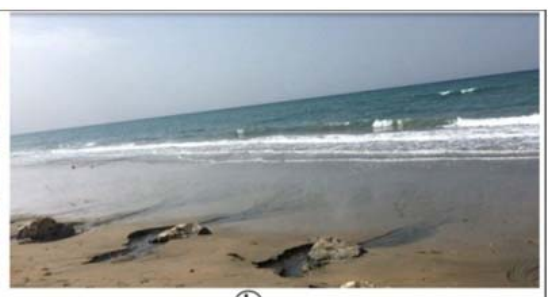

(b)

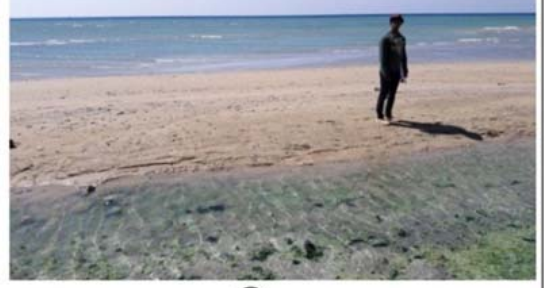

(d) 


\section{Geotouristic potentiality of Hammam Faraun geothermal area}

The spring's water is undrinkable; its physicochemical parameters are listed in table 3. Temperature is near $70^{\circ} \mathrm{C}, \mathrm{pH}$ is near neutral, TDS points to a high salinity exceeding $19000 \mathrm{ppm}$. The water contains the combination of the main cations $\left(\mathrm{Ca}^{2+}, \mathrm{Mg}^{2+}, \mathrm{Na}^{+}, \mathrm{K}^{+}\right)$, anions $\left(\mathrm{H}_{4} \mathrm{CO}^{3-}, \mathrm{Cl}^{-}, \mathrm{SO}^{2-}\right)$ and specific trace amounts of metals as $\mathrm{Fe}, \mathrm{Ba}, \mathrm{Mn}$ and $\mathrm{Zn}$ (Table 3).

In order to reveal the origin of such thermal water, Sulin's diagram (Sulin, 1948) is used. According to the Sulin's diagram (Fig. 11), the sample plots in the lower triangle of the upper quadrant (recent marine water triangle) but not far from the meteoric water triangle. This point to a mixed origin marine and meteoric water origin. The hypothetical salt combinations are: $\mathrm{KCl}, \mathrm{NaCl}, \mathrm{MgCl}_{2}, \mathrm{MgSO}_{4}, \mathrm{CaSO}_{4}$ and $\mathrm{Ca}$ $\left(\mathrm{HCO}_{3}\right)_{2}$. It is worth to mention that dissolution of the country rock Eocene carbonates and Miocene evaporites plays important role in the chemical composition of such water (Issar et al. (1971), Sturchio et al. (1996), El-Fiky (2009); Abdel Zaher et al. (2011).

Table 3: Chemical analysis of a representative sample of the thermal springs water of Hammam Faraun area. Concentrations of major cations and anions are given in $\mathrm{mg} / \mathrm{l}(\mathrm{ppm})$ as well as in meq/l (epm). In addition, concentrations of some trace elements are given in $\mathrm{mg} / \mathrm{l}(\mathrm{ppm})$.

\begin{tabular}{|l|l|l|l|l|l|l|l|l|l|}
\hline Physiciochemical Parameters & \multicolumn{3}{|c|}{ Major Cations } & \multicolumn{3}{c|}{ Major Anions } & \multicolumn{2}{c|}{ Trace Elements (ppm) } \\
\hline $\mathrm{T}\left({ }^{\circ} \mathrm{C}\right)$ & 68 & & $\mathrm{ppm}$ & epm & & $\mathrm{ppm}$ & $\mathrm{epm}$ & $\mathrm{Fe}$ & 0.508 \\
\hline $\mathrm{pH}$ & 7.65 & $\mathrm{Na}$ & 5280 & 229.6 & $\mathrm{Cl}^{2}$ & 8368 & 236 & $\mathrm{Ba}$ & 0.13 \\
$\mathrm{TDS} \mathrm{mg} / \mathrm{l})$ & 19380 & $\mathrm{Ca}$ & 1152 & 57.5 & $\mathrm{SO}_{4}$ & 3866 & 80.5 & $\mathrm{Mn}$ & 0.085 \\
& & $\mathrm{Mg}$ & 346 & 28.5 & $\mathrm{HCO}_{3}$ & 134 & 2.2 & $\mathrm{Zn}$ & 0.041 \\
& $\mathrm{~K}$ & 121 & 3.1 & & & & & \\
\hline
\end{tabular}

The high sulfurous content is noticed from the strong "rotten egg" smell of the springs. The thermal water of $\mathrm{HF}$ area has balneotherapic benefits where it is believed to help in treating some diseases due to its dissolved components.

Particularly, among the many different types of thermal waters, sulfurous thermal waters have been emphasized for the potential use for destressing, healing, and treatment of several inflammatory diseases, mostly at dermatological, bronchoalveolar, and osteoarticular levels. Other dieses reported to be cured using these waters include gynecological disorders, rheumatism, liver and gastrointestinal disorders, osteoporosis, and nervous system disorders. Beside the healing effect of hyperthermia, many authors have showed the therapeutic effects of curing baths, gases, and muds in hot springs areas. Hyperthermia causes dilatation of blood capillaries by water temperature and increasing blood flow to the inflamed parts. Moreover, sulfur compounds break disulfide bonds of the mucin and activate breathing and blood circulation and help to reduce inflammation. Other constituents such as $\mathrm{Mg}, \mathrm{Na}$ and $\mathrm{Cl}$ contribute to the therapeutic effects of such water (e.g. Saber. 2013; Kiełczawa, 2018; Davinelli et al, 2019 and references therein).

HF thermal spring waters can be used as a source of clean geothermal energy. Numerous geothermal studies concluded that the area is one of the most promising sites for geothermal energy production in Egypt due to high geothermal gradient and heat flow. These studies attributed the heating of the geothermal waters to the uplift of the basement rocks and the circulation of waters along the fault system (e.g. Abdel Zaher et al., 2012; Lashin, 2013). However, Shawky et al. (under publication) points to the role of the volcanic activity of the area in the heating process. The geologic significance of these hot springs is primarily included in their association with a faulting in a rift setting, present-day active geothermal phenomenon related to continuous geothermal flow, and promising use in power generation. This geologic significance, together with their balneotherapic importance give them a high geotouristic potentiality which is increasing with public's increased interest in natural therapies and natural health promotion.

\section{Karstic caves}

Karstic features are special geotouristic attractions at the northern part of the area. Gebel Hammam Faraun contains some small cavities and two major caves which represent natural karstic features, further widened by human use (Fig. 12 a, b \& c). The caves lead to some chambers inside. Calcite precipitations, gypsum, some bubble features, some small speleothems, and Terra Rossa characterize the walls and the 
ceilings. The temperature is very high due to hot vapors from springs inside. The extreme heat increases inward. Fractures in the cave walls and ceilings emit heat that can be easily felt (Fig. $11 \mathrm{c} \& d$ ). An examined opened fracture has a dip of $16^{\circ}$ in NW direction from which strong heat is released. Another fracture which is filled is dipping $24^{\circ}$ towards NE direction. The wall between the caves is fractured and exists on the fault plane.

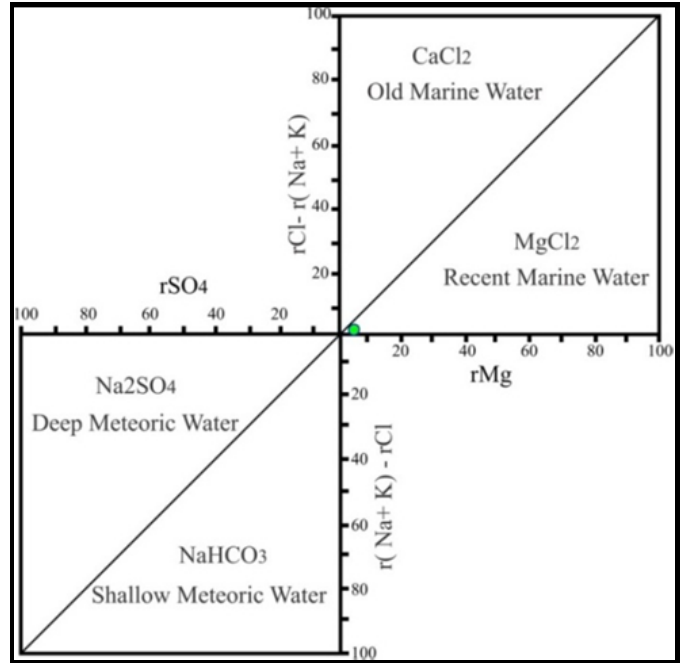

Fig. 11: Plotting of the studied water sample of HF hot springs on Sulin's diagram (Sulin, 1948) for genetic classification of Groundwater.

Steam of the geothermal water inside the caves turned them into natural saunas that attract visitors to such place. Thus, it represents an important therapeutic tourism spot.

Such karst topography and caves are formed by karstification of the Thebes Carbonate. This karstification process is associated with underground hydrothermal solution percolation along the highly fractured Thebes limestone coupled with repeated runoff during the Quaternary (mainly Pleistocene) pluvial periods.

Karstic features in general and caves in particular have high natural value due to their unusuality and diverse features including both dissolution and deposition forms. Moreover, they represent an interaction between surface and ground waters and provide valuable geologic records of paleoclimate, paleogeography, and tectonics of a certain geologic area.

Therefore, the coupling of the therapeutic uses of Hammam Faraun caves as a natural spa together with its significant geologic value as karst landforms that represent outstanding elements in geotourism at national and international scale provides a high geotouristic potentiality of such features.

\section{Travertine}

Travertine represents an attractive feature in HF area. They have been documented for the first time in the study area by Shawky et al. (under Publication) and have been suggested to be of Pleistocene age. They are deposited along the steep slope of Gebel Hammam Faraun. Some emerged parts of these deposits occur in the form of fractured patches of an area about $1 \mathrm{~m}^{2}$ (Fig. 13). Such patches cover small areas along fissures that have no sources of spring water todays.

HF travertine deposits are hosted in the Eocene carbonates of the Thebes Formation. They made up of light beige-colored thin carbonate thin layers striking NW-SE (Fig. 13). Small bulbous cavities are found in the travertine representing the degassing process during the formation of such deposits. The deposits are commonly associated with matrix of sand to gravel-sized fragments of carbonates (mainly of the hosting dolostones), basaltic fragments, and fossil plant remains.

The studied petrographic thin sections for this travertine show alternating laminations of bacterial/micritic dendritic clumps or clusters and sparite crystals with encrusted lithified gas bubbles (Fig. 14). Mineralization rims "from hydrothermal solutions" exist on the outlines of the sparite crystals. Moreover, fragments from the country rocks do exist. 
Geotouristic potentiality of Hammam Faraun geothermal area

Fig. 12: Field photos for the karstic caves of Hammam Faraun area. a) General view of the karstic caves and the facing part of the thermal springs area. b) the small cave (cave 1) from outside c) The Large cave (cave 2) from outside. d, e) The small and the large caves from insides respectively with obvious fractures in the walls and ceilings.

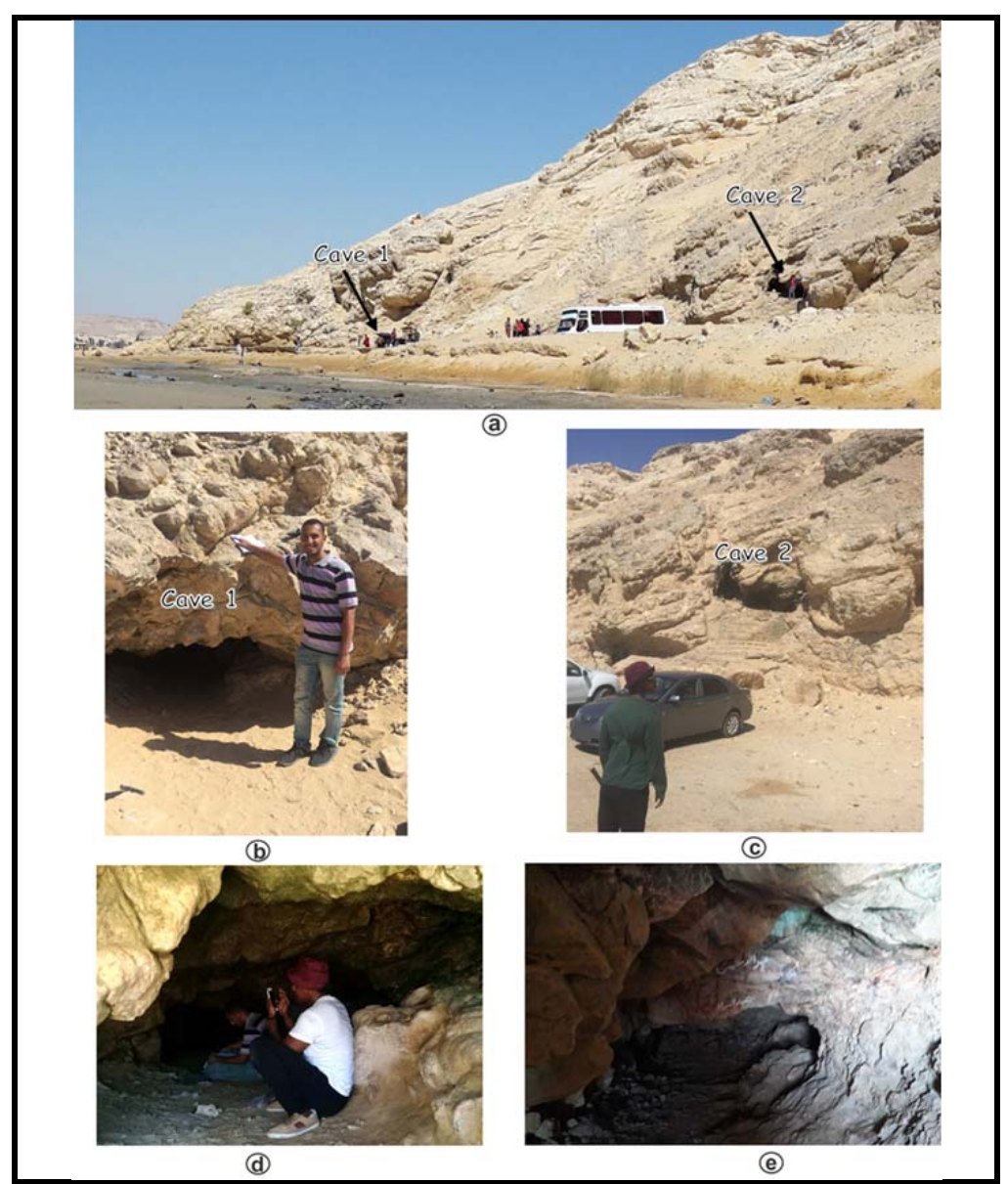

We propose an order for the genesis of HF travertine that begins with the growth of bacterial or algal micritic shrubs on a substrate followed by microbially induced precipitation of carbonate crystals then the formation of mineralization rims around the sparite by the hydrothermal fluids. Brecciation and accumulation of detrital fragments form the country rocks might took place by the effect of hydrothermal fluids and or structural activities.

Such travertine indicates the old hydrothermal activity in the area along HFF where the ancient springs formed hanged ponds where travertine was deposited by combined biotic and abiotic (mainly geothermal) processes.

Travertine of HF area owe their future geotouristic potentiality for being geotouristic unique features at least at the local scale. These deposits preserve the geologic history where they serve as analogues of old (yet continuous) geothermal activity of HF area and provide insights on paleoclimate and paleogeography of the area. However, their restrictions in small patches may lower their geotouristic interest.

\section{Volcanic bodies}

Interesting volcanic occurences related to the Gulf of Suez rifting exist in HF area. This Tertiary (Oligo-Miocene) basaltic volcanic activity is clarified by dikes, sills and flows which invaded the pre-rift sedimentary sequence. They were previously dated and given the age of 22- $24 \mathrm{Ma}$ using the K-Ar (Steen, 1984; Moussa, 1987). They are hypabyssal as well as extrusive dolerites and basalts. These volcanic occurrences are exemplified in a studied sill, dyke and flow (Fig. 15).

The basaltic sill exists at the south-eastern part of the area. The basalt is highly altered and fractured, brownish in colour. The fractures are filled with gypsum. It is a thick sill between the Matulla Formation and Sudr Chalk. 


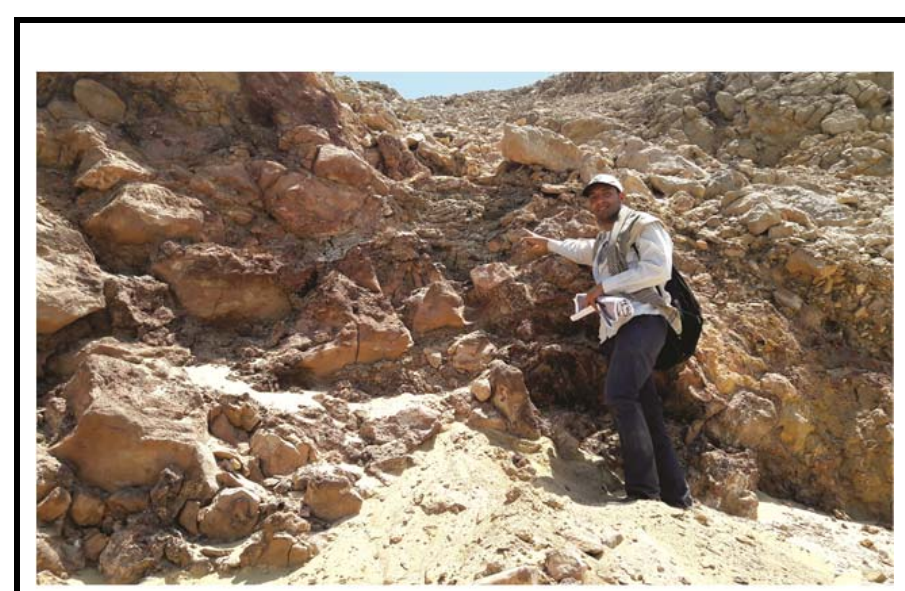

(a)

Fig. 13: Distant view Hammam Faraun Travertine. b) vuggy crystalline layered calcite $c$ ) magnified view of $b$ shows a layered texture. Some reveal a spiky surface texture possibly resulting from dissolution.

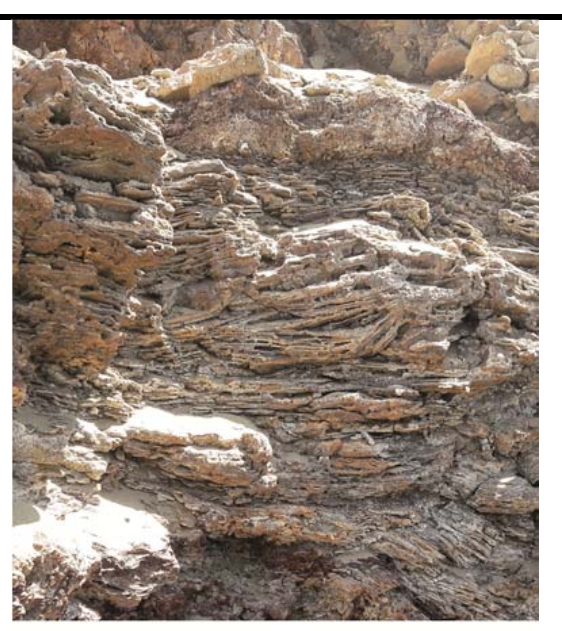

(b)

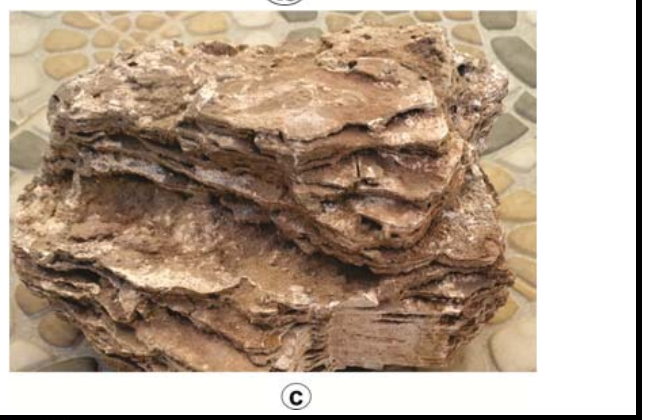

C

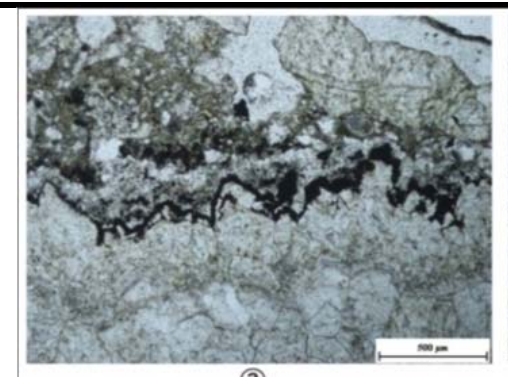

(a)

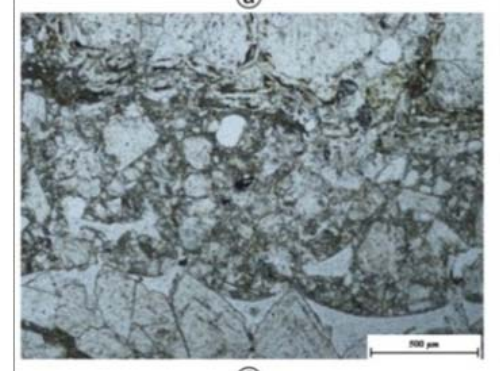

(C)

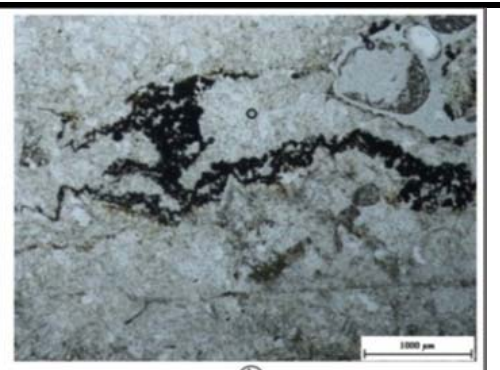

(b)

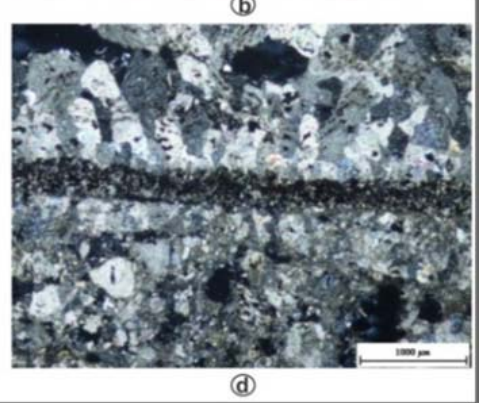

Fig. 14: a) Dense sharply defined irregular laminations of bacteria. b) Clumps which represent loci of previous sites of bacteria and are surrounded by clear spar. c) Laminated micrite layers bordering voids which are partly filled with bladed prismatic "Dogtooth" sparite with obvious mineralization rims. d) Rock fragments from the surrounding rocks included within the travertine.

A small short basaltic dyke is found south to the sill. The dyke is trending in NE-SW direction with a thickness reaching up to $15 \mathrm{~m}$ in its widest area. The basalt is whitish green and spheroidally weathered with hard and massive blackish blocks floating in the highly weathered matrix. The dyke extends from the Gulf of Suez shore to the mountain climbing all the rocks and spreading on the Matulla Fm. Most probably, it found its pathway along the fault separating the Matulla Fm. from the Sudr Fm. (Gebel Fault 2) evidenced by the reddish color on the wall of the dyke. A ring dyke is found in the area where two intersections are observed in the Gebel Hf cliff. The first intersection trends NE-SW while the other trends NW-SE producing a ring dyke. The joining of these two intersections is observed in the map view where the whole dyke is trending in NW direction. 
Geotouristic potentiality of Hammam Faraun geothermal area

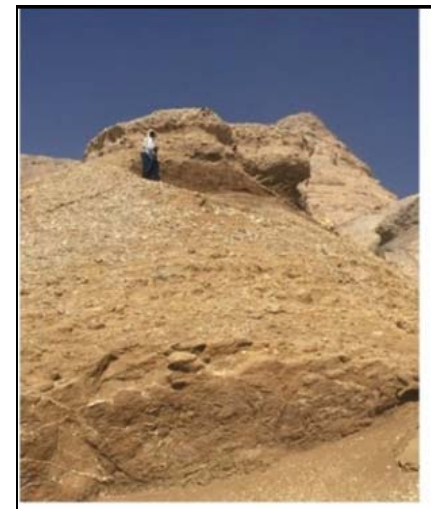

(a)

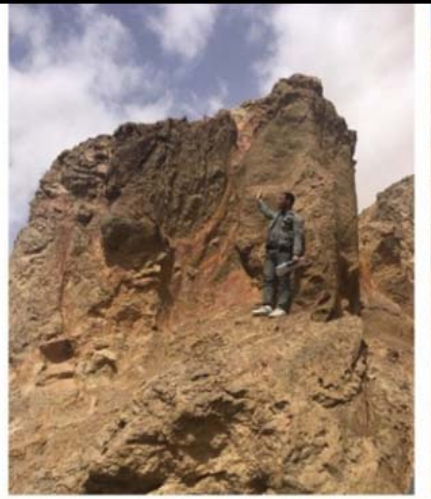

(b)

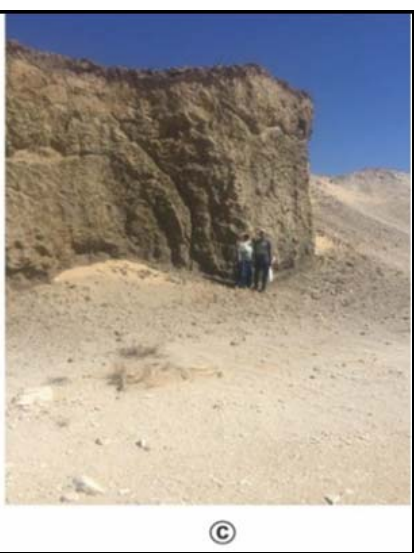

Fig. 15: Field photographs of the different Hammam Faraun volcanic bodies a) sill. b) dyke. c) flow.

Lava Flows are located at the north-western sector of the area. They are topped by the Miocene clastics and underlain either by the Oligocene Abu Zenima FM. or the Late Eocene Tanka Fm., specifically in areas where the Oligocene is missed due to faulting.

The petrographical study revealed two mafic varieties of the volcanic rocks: olivine dolerite and plagioclase-phyric basalts (Fig. 16). The dolerite is encountered in the interior of the sill as well as xenoliths in the lava flows. It is medium-grained, holocrystalline, and composed mainly of plagioclase, augite, and olivine with different degrees of deuteric alteration to iddingsite and serpentine. On the other hand, the dykes, the flows, and the margins of the sills are composed of fine-grained, holocrystalline to cryptocrystalline plagioclase-phyric basalts with clayey alterations. Calcitization, alterations and mineral fillings in these basalts indicate the volcanic- country rock interaction as well as the impact of the geothermal fluids.

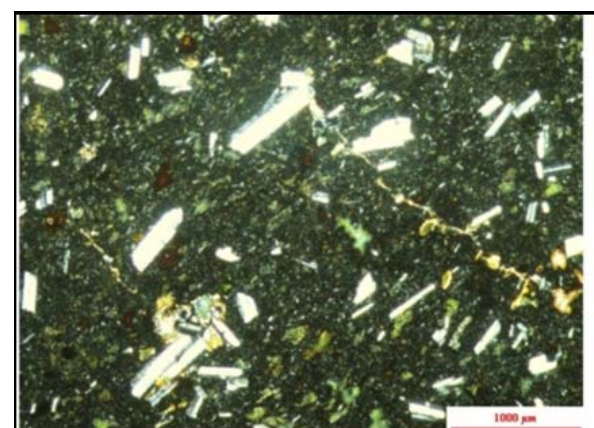

(a)

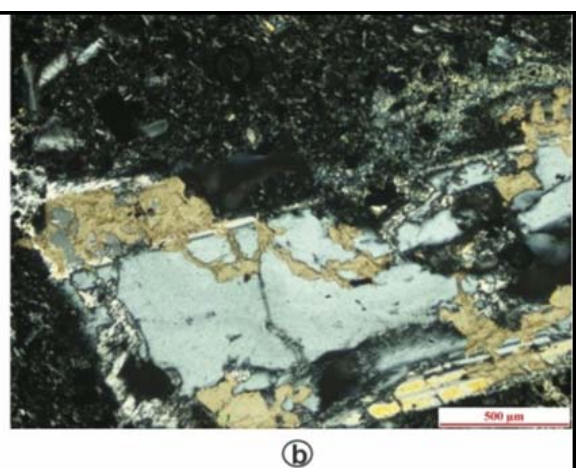

(b)

Fig. 16: The two mafic varieties of Hammam Faraun volcanics under microscope. a) doleritic basalt. b) Plagioclase phyric basalt.

\section{Current situation of the area}

The area has been historically an important touristic attraction in Sinai. Main activities done by visitors include hot water bathing and inside-caves sauna. Lack of many main facilities that should be found in a geothermal tourist site is a great issue where there are no housings, toilets, instructions, tour guides, etc. However, new resorts are being constructed nearby. Repeatedly, the area is getting closed due to some security reasons and accidents. Asphyxiation accidents are the main, others include fall of the mountain. Lack of safety instructions and medical aid is an important issue in the area.

\section{CONCLUSIONS AND RECOMMENDATIONS}

Hammam Faraun geothermal area contains some geological attractions with promising geoheritage value besides promising geothermal energy resources. These attractions have been inventoried in this study. Geoheritage elements that include thermal springs, karstic caves, volcanic bodies, spring (travertine) deposits together with the mountainous-shore landscape favor the geotouristic potentiality of 
the area. The interrelationship between the hot springs, karstic caves, travertine and volcanic bodies can be an important attraction for geotourists who seek increasing their knowledge about geological processes. Geotourism can be developed through some activities and programs such as thermal water bathing, geohiking, cave exploration and geo-educational events.

Geologists play an important role to identify, to map, and to promote the geotourism potentials of the area. However, the area lacks geologic guides who can explain its geological significance to visitors and help them understand and appreciate its significance to the Egyptian heritage and the importance of its conservation. Providing the area with such specialists can be an important tool the management of geoheritage as a part of a policy for the sustainable development of tourism. Another issue is the lack of facilities in the area such as lodges, toilets, etc. Safety instructions, first aid and oxygen tubes for the visitors at the caves are also missing.

It is recommended that the local authorities should implement strategies to resolve these issues for increasing the potential of the area.

Further development of a geothermal energy project in the study area gives the opportunity to develop the area as a clean energy- based sustainable touristic community. Which in turn, can improve Sinai's economy, decrease poverty, and increase public awareness aboutgeology and environment?

\section{REFERENCES}

Abdel Maksoud, K. M., and Hussien, M. G. (2016): Geotourism in Egypt and its economic and culture impact. Arab. J. Earth Sci. 3(1), 1-13.

Abdel Zaher, M. A., Ehara, S., El- Qady, G. (2011): Conceptual model and numerical simulation of the hydrothermal system in Hammam Faraun hot spring, Sinai Peninsula, Egypt. Arab. J. Geosci 4(12):161-170

Abdel Zaher, M. A., Saibi H., Nishijima J., Fujimitsu Y., Mesbah, H. and Ehara, S., (2012): Exploration and assessment of the geothermal resources in the Hammam Faraun hot spring, Sinai Peninsula, Egypt. J. Asian Earth Sci., 45:256-267.

Davinelli, Sergio, Franco Bassetto, Marco Vitale, and Giovanni Scapagnini. (2019): Thermal Waters and the Hormetic Effects of Hydrogen Sulfide on Inflammatory Arthritis and Wound Healing. In: The Science of Hormesis in Health and Longevity, 121-126. Academic Press.

Dowling, R. K., Newsome, D. (Eds.). (2006): Geotourism. Elsevier Butterworth Heinemann, 260p.

El-Fiky, A. A. (2009): Hydrogeochemistry and geothermometry of thermal groundwater from the Gulf of Suez Region, Egypt. J. KAU Earth Sci., 20(2):71-96.

Erfurt-Cooper, P. (2010): The importance of natural geothermal resources in tourism. In: Proceedings of World Geothermal Congress, Bali, Indonesia, pp. 25-9.

Erfurt-Cooper, P., Cooper, M. (Eds.). (2010): Volcano and geothermal tourism: sustainable geo-resources for leisure and recreation. Earthscan, $400 \mathrm{p}$.

Farsani, N. T., Coelho, C. O. A., da Costa, C. M. M., and de Carvalho, C. N. (2012): Geoparks and Geotourism. New Approaches to Sustainability for the 21st Century; Brown Walker Press: Boca Raton, FL, USA, 207p.

Gawthorpe, R. L., Jackson, C. A. L., Young, M. J., Sharp, I. R., Moustafa, A. R. and Leppard, C. W. (2003): Normal fault growth, displacement localization and the evolution of normal fault populations: the Hammam Faraun fault block, Suez rift, Egypt. J. Struct. Geol., 25(6), 883-895.

Geological Society of America (GSA), (2012): Geoheritage, GSA Position Statement, 4 p. Downloaded from: https:// www. geosociety. org/documents/gsa/positions/pos20 Geoheritage.pdf.

Hiran, i. J. (2014): Diagenetic evaluation of fault/fracture related dolomitisation, Cretaceous- Eocene, Hammam Faraun Fault Block, Gulf of Suez. Ph. D. thesis, University of Manchester, Manchester, United Kingdom, 295p.

Hirani, J., Bastesen, E., Boyce, A., Corlett, H., Gawthorpe, R., Hollis, C., John, C. M., Robertson, H., Rotevatn, A., and Whitaker, F. (2018a): Controls on the formation of stratabound dolostone bodies, Hammam Faraun Fault block, Gulf of Suez. Sedimentology 65(6):973-2002. 


\section{Geotouristic potentiality of Hammam Faraun geothermal area}

Hirani J., Bastesen, E., Boyce, A., Corlett, H., Eker, A., Gawthorpe, R., Hollis, C., Korneva, I., and Rotevatn, A. (2018b): Structural controls on non-fabric-selective dolomitization within rift- related basin-bounding normal fault systems: Insights from the Hammam Faraun Fault, Gulf of Suez, Egypt. Basin Res 30(5):990-1014.

Hollis, C., Bastesen, E., Boyce, A., Corlett, H., Gawthorpe, R., Hirani, J., Rotevatn, A., Whitaker, F. (2017): Fault-controlled dolomitization in a rift basin. Geology, 45(3), 219-222.

Issar, A., Rosenthal, E., Eckstein, Y., Bogoch, R. (1971): Formation waters, hot springs and mineralization phenomena along the eastern shore of the Gulf of Suez. Bull Int Assoc Sci Hydrol 16, 25-44.

Kiełczawa, B. (2018): Balneological use of geothermal springs in selected regions of the world. In: J. Bundschuh, B. Tomaszewska (Eds.) Geothermal Water Management, Geothermal Water Management, Taylor \& Francis Group, London (pp. 319-364). CRC Press.

LaMoreaux, P. E. (2001): Historical development. In LaMoreaux, P.E. \& Tanner, J. T. (eds) Springs and Bottled Waters of the World (pp. 15-32). Springer, Berlin, Heidelberg.

Lashin, A. (2013): A preliminary study on the potential of the geothermal resources around the Gulf of Suez, Egypt. Arab J Geosci 6(8):2807-2828

Migoń, P., Pijet-Migoń, E. (2017): Interpreting geoheritage at New Zealand's geothermal tourist sitesSystematic explanation versus storytelling. Geoheritage, 9(1), 83-95.

Moon, F. W., Sadek, H. (1923): Preliminary geological report on Wadi Gharandel area (north of Gebel Hammân Faraûn, Western Sinai). Petroleum Research Bulletin, 12, Government Press, Cairo, 42 pp.

Moussa, H. E., (1987): Geologic studies and genetic correlation of basaltic rocks in West Central Sinai. (Ph.D. Thesis) Ain Shams Univ (308 pp.).

Moustafa, A. R. and Abdeen, A. R. (1992): Structural setting of the Hammam Faraun Block, eastern side of the Suez rift. KJS 19, 291-310.

Moustafa, A. R. (1996): Structural setting and tectonic evolution of the northern Hammam Faraun Block (Wadi Wasit-Wadi Wardan area), eastern side of the Suez rift. Kuwait J. Sci. Eng. 23, 105-131.

Moustafa, A. R., and Khalil, S. M. (2020): Structural Setting and Tectonic Evolution of the Gulf of Suez, NW Red Sea and Gulf of Aqaba Rift Systems. In: Hamimi Z., El-Barkooky A., Martínez Frías J., Fritz H., Abd El-Rahman Y. (eds) The Geology of Egypt. Regional Geology Reviews. Springer, Cham.

Newsome, D and Dowling, R. K. (2010): Geotourism: the tourism of geology and landscape. Goodfellow Publishers, Oxford, $320 \mathrm{p}$.

PROGEO, (2011): Conserving our Shared Geoheritage - A Protocol on Geoconservation Principles, Sustainable Site Use, Management, Fieldwork, Fossil and Mineral Collecting.

Saber, A. I (2013): Water Springs in Hammam Faraun Area on the Eastern Coast of the Gulf of Suez as a Model for the Thermal and Sulfur Springs "A Study in Physical Geography". MERCJ 33 (print), 33-80.

Shawky, A., El-Anbaawy, M. I., Shallaly N. A., Shaheen, E. N. (under publication): Continuous fluid circulation in Hammam Faraun geothermal system, Gulf of Suez rift, Egypt: evidences from hydrothermal deposits along rift-related faults. Carbonates Evaporites.

Steen, G. (1984): Radiometric age dating of some Gulf of Suez igneous rocks. Proceedings of the 6th Exploration Seminar, Cairo, March, 1982, 1. Egyptian General Petroleum cooperation and Egypt petroleum exploration society, Cairo, 199-211.

Sturchio, N. C., Arehart, G. B., Sultan, M., Sano, Y., AboKamar, Y., and Sayed, M. (1996): Composition and origin of thermal waters in the Gulf of Suez area, Egypt. Appl Geochem 11:471-479.

Sulin, V. A. (1948): Basis of classification of natural water. Gostoptechizdet Moscow. In Russian).

Whaley, J. (2006): Egypt's Secret Treasure. GeoExPro magazine. 3(4): 62-66. Downloaded from: https: // assets.geoexpro. com/legacy-files/articles/Geotourism \%20 Egypt. pdf 


\title{
إمكانيات السياحة الجيولوجية بمنطقة حمام فرعون الجيو حرارية ، محافظة جنوب سيناء، مصر
}

\author{
أحمد شوقي (، محمد ابراهيم الانبعاوي (، نهلة أحمد شلالي (، هشام عبد عبد الحفبظr \\ ا قسم الجيولوجيا، كلية العلوم، جامعة القاهرة، الجيزة، مصر \\ r المعهد القومي للبحوث الفلكية و الجيوفيزيقة ، حلوان، القاهرة، مصر

\section{الخلاصة}

تعتبر منطقة حمام فرعون واحدة من المناطق الجيوحرارية الرئيسية في مصر ، و لذلك نقوم الدراسة الحالية بجرد وتقييم عوامل الجذب السياحي الجيولوجي بها ـ وتتمنل عوامل الجذب السياحي الجيولوجي في هذه المنطقة في جيل فئل حمام فرعون ،

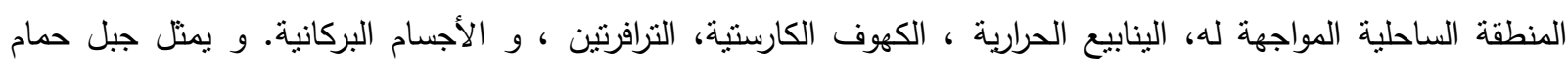

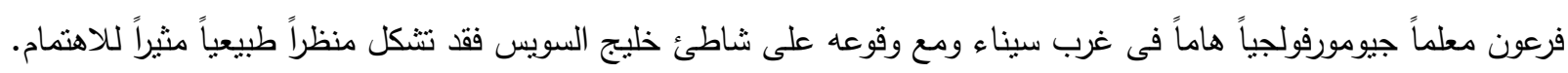

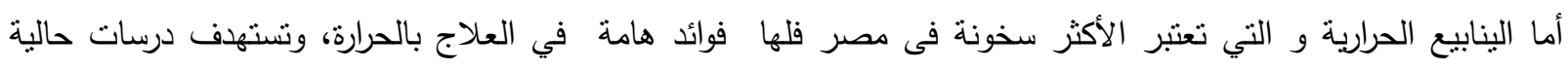

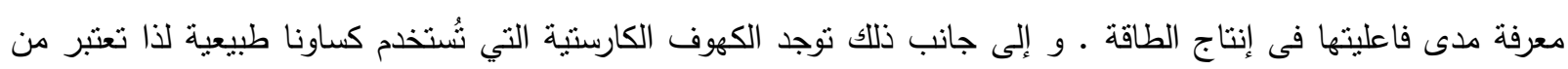
معالم الجذب الجيوسياحية الهامة في المنطقة.

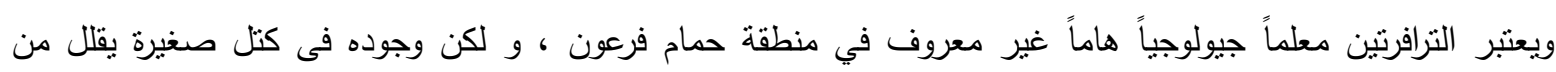

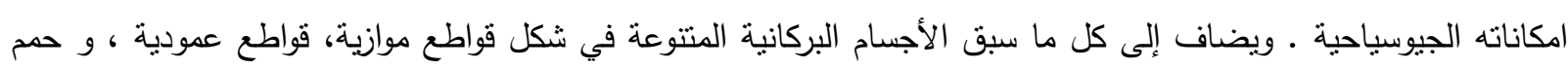

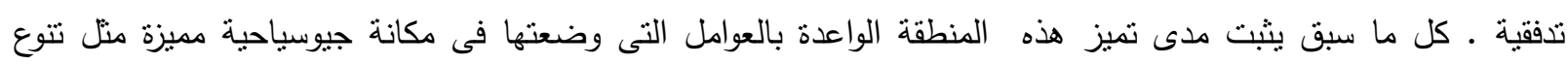

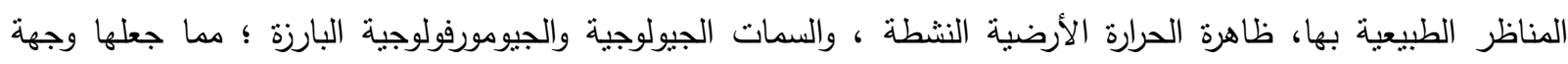

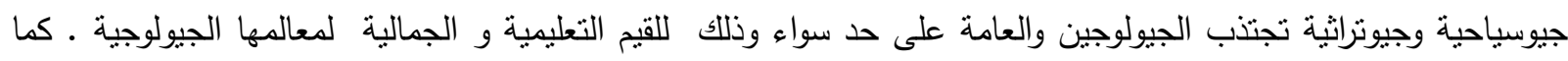
تقدم الدراسة الحالية بعض التوصيات لنطوير السياحة الجيولوجية فى المنطقة ، وعلاوة على ذلك فإن اقتران استخدام الطاقة

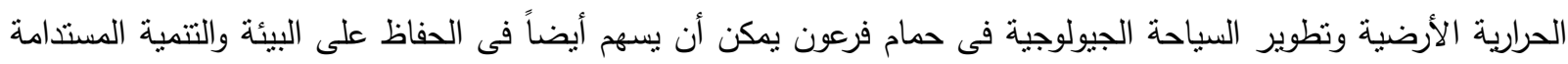
فى شبه جزيرة سيناء . 